\title{
Rice Gene Pool for Tarai and Inner Tarai Areas of Nepal
}

\author{
Bal K Joshi \\ Biotechnology Unit-NARC, Khumaltar, PO Box 1135, Kathmandu <joshibalak@rediffmail.com>
}

\begin{abstract}
Knowledge on crop gene pool helps to develop varieties, to know the potential sources for breeding materials and to develop strategy for sustainable use and conservation. The amount of genetic diversity presents depends on the number and diversity of the original ancestors involved in the creation of a germplasm pool, existing landraces and wild species. The objective of this research was to study the diversity of rice gene pool present in the Nepalese improved rice cultivars and landraces adapted to Tarai and Inner Tarai $(<1000 \mathrm{~m})$. Pedigrees of 28 Nepalese rice cultivars were examined and surveyed the literature for distribution of landraces and wild relatives of rice. Crosses among indica rice gene pool are more common and use of japonica and nivara species were less common. There are 28 improved rice cultivars, $>500$ landraces, and 6 wild species and relatives of rice adapted to Tarai and Inner Tarai. Eight countries are the origins for 28 cultivars. In Nepal 4 cultivars were bred and developed using a local landrace and exotic genotypes. A total of 35 ancestors originated in 11 different countries were used to develop these 28 cultivars. Highest number of ancestors was from India. Use of ancestors of both sativa and nivara species having indica and japonica types indicated the collection of wide gene pool. Most of the ancestors were sativa (60.00\%) and indica (65.71\%). Genetic erosion is observed in rice diversity therefore, in situ, on farm and ex situ conservations are necessary for maintaining the genetic variation. Utilization of local landraces in breeding program may be the good way of genetic resources conservation. Gene pool from these landraces along with international gene pool could make towards success in developing high yielding cultivars with wide adaptability and/or site specific. In this study, cultivars and landraces surveyed represent a wide range of variation for different areas of origin and adaptation. This genetic diversity is very useful for further rice improvement and should be conserved both ex situ and in situ.
\end{abstract}

Key words: Ancestor, Landrace, Nepalese rice cultivar, Rice gene pool, Tarai and Inner Tarai

\section{INTRODUCTION}

Rice is a staple food crop and plays an important role in Nepal's economy. Different kinds of landraces and wild rice in Nepal are reported by Mallick (1981/82), Sherchand et al (1998), Joshi et al (1998), Shrestha and Upadhyay (1999), Rana et al (2000a, 2000b, 2000c), Adhikari et al (1995) and Gupta et al (2000). About 2000 rice landraces are reported in Nepal growing from 60 to $3050 \mathrm{~m}$ altitude (Mallick 1981/82). Rice samples of 500 years ago are found at Simraungardh, Bara (Mallick 1981/82) which support the statement that Nepal is one of the centers of rice diversity. During mid 1960s the yield potential of semi dwarf high yielding varieties initiated a scope for raising rice production in the country. Several exotic varieties were obtained through IRRI and Taiwan (NRRP 1997a). Rice research was initiated in 1951 (Mallick 1981/82) and National Rice Improvement Program was established in 1972 at Parwanipur to organize the research and development works on rice as a commodity crop. So far there are 48 improved rice cultivars recommended for cultivation. Among them 28 are recommended for Tarai, Inner Tarai and Foot Hills of Nepal. 
Genetic diversity is necessary to derive different transgenic segregants suitable for different agroecology and to meet the needs of farmers. The main source of the diversity for development of modern varieties is the traditional varieties that have been grown and selected for generations by rice farmers. All modern varieties can be traced back to landraces. Both the potential for long term genetic gain and the reduction of genetic vulnerability may depend on the genetic diversity present in the genetic base of the crop. The amount of genetic diversity presents depends on the number and diversity of the original ancestors involved in the creation of a germplasm pool, existing landraces and wild rice and their relatives. The level of genetic variation present in gene pools of most important crops has been analyzed by studying the pedigree relationship between cultivars. Kinship coefficients estimation of cultivars of oat (Souza and Sorrells 1989), soybean (Cox et al 1985a), wheat (Joshi et al 2004), winter wheat (Cox et al 1985b), rice (Dilday 1990) and barley (Martin et al 1991) has shown that a restricted number of ancestral genotypes account for a large proportion of the variation present in released cultivars. The pedigrees of IRRI varieties upto 1994 have been traced back to 40 landraces from 12 different countries (de Leon and Carpena 1995). Diversity of rice considering ancestors of cultivars, wild relatives and landraces should be assessed for effective conservation and utilization of rice gene pool. Information on cultivars diversity based on pedigrees is useful for risk assessment on concern cultivar. Equally, such types of analysis explain how the breeders are able to capture genetic diversity in a cultivar. Therefore study was focused here on landraces and wild rice diversity and its distribution in Nepal and countries from where genes were introduced through improved cultivars in Nepal particularly in Tarai and Inner Tarai areas.

\section{METHODOLOGY}

In this study basically diversity on landraces in terms of their name, improved cultivars in terms of their ancestors and origin and wild rice in terms of species distribution were assessed. Literature related to rice exploration, improved cultivars recommended for Tarai and Inner Tarai and Nepalese landraces adapted to Tarai and Inner Tarai and wild rice and their relatives were reviewed. Three sites, National

Rice Research Program (NRRP), Haridnath; Regional Agriculture Research Station, Parwanipur, and Plant Genetic Resources (PGR) Unit, Khumaltar were visited. PGR Unit has collected and conserved many rice landraces. Rice genotypes available in Nepal were categorized under four groups 1. Landraces, 2. Improved cultivars, 3. Ancestors of these cultivars and 4. Wild rice and their relatives. Unique and endangered rice landraces were compiled. Based on collection data, landraces and wild species distribution were indicated in Nepal map. Landrace diversity based on different name was compiled with respect to districts. It is assumed to estimate the landrace richness that rice landrace is different if the name given by farmer was different. Frequency of rice accessions collected from different districts and conserved in PGR Unit was computed. Altogether 28 cultivars had been released for Tarai and Inner Tarai and Foot Hills in Nepal from 1959 to 2002. Here in this study the pedigrees of these 28 cultivars were examined. Study shows that most of the cultivars were introduced either from IRRI or India. The pedigrees of these rice cultivars were traced back to their ancestors that had no known relationship with each other. One example of the cultivar back to ancestors is given in Figure 1. The source of improved cultivars, their pedigree and release dates were Mallick (1981/82), IRRI (1970, 1987, 2000a, 2000b), NRRP (1992, 1997a), NRRP (1997b) and IRRI (GEU). Origin of ancestors, their group and species were identified. Diversity was studied on improved cultivars based on their origin, types and number of ancestors and ancestors' types. Countries from where the genes introduced in Nepal were located in world map based on the origin of ancestors of Nepalese improved rice cultivars. 


\section{RESULTS AND DISCUSSION}

The land in Nepal has the largest variations in altitude in the world. Three types of land Bari, Khet and flat and fertile with good soil depths produce rice indicating the diverse rice genotypes adopted to different production environments. Rice is grown mainly as Barkhe crop sown in June/July and harvested in Sept/Oct. It is also grown as Hiunde (winter rice popularly known as Boro rice) and Chaite dhan. Due to the varied agroecological diversity of the country, it is possible to plant same cultivar in Barkhe, Hiunde and Chaite seasons. Nepal posses many diversity in rice however, under the CGIAR system Nepal received a lot of rice genotypes. Landraces are diverse in maturity period, photoperiodism, growing seasons, adaptation to different cropping systems and cultural practices and dormancy. Rice can be observed in the field all year round somewhere in Nepal.

\section{Exploration and collection}

Ten international exploration missions have targeted cultivated and wild rice species in Nepal (Upadhyay and Joshi 2003). Forty exploration programs were carried out in different parts of Nepal to collect different crops species by international organizations from 1937 to 2000. The countries/ organizations involved in exploration missions are Germany, Japan, UK, IRRI, FAO, IBPGR and USAID. A total of 1550 different rice varieties from Nepal have been collected from altitude of 60$3050 \mathrm{~m}$ and conserved at IRRI, Philippines (Shrestha and Vaughan 1989). National organizations mainly by Agriculture Botany Division (ABD), Khumaltar had explored different crop species 22 times in different parts of Nepal. They have targeted 7 times to rice both cultivated and wild from 1981 to 2000 (Gupta et al 2000). There are 615 landraces, which are differed by name collected from Tarai and Inner Tarai and conserved in ABD. These are collected from different altitude ranging from 65 to 1000 $\mathrm{m}$. There may be many landraces that are genetically same but differed only by name or vise versa. These need to verify. ABD has 2963 accessions of rice landraces and 144 accessions of wild rice collected from all over the country (Gupta et al 2000). These are conserved ex situ at medium term storage facility in Khumaltar.

\section{Landrace gene pool}

$\mathrm{ABD}$ has representative rice landraces from 73 districts of Nepal (Table 1). Highest number of rice accessions among the 33 Tarai and Inner Tarai districts was collected from Sunsari $(3.88 \%$ of total accessions) followed by Dhanusha (3.37\%), Parsa and Bara. Collection sites of 197 accessions were not known. Sunsari, Dhanusha, Parsa and Bara may be the focal area in term of rice landraces diversity in Tarai and Inner Tarai. Lumle Agriculture Research Station (LARS) and NRRP, Hardinath have also maintained some landraces and ABD has 1608 accessions of rice adapted to Tarai and Inner Tarai. There may be duplicate accessions in these three places. Removing duplicate accessions and adding new one should be made continuously. Extensive survey and duplication study of accessions could help to control genetic erosion and conservation cost. Many of these landraces are still grown by farmers. These landraces have a wide range of natural adaptation to withstand varied abiotic and biotic conditions. In addition, these landraces have high tillering ability, withstand severe drought stress, have good quality grains and adapted to marginalized areas.

Table 1. Total rice accessions and frequency collected from different districts of Tarai and Inner Tarai of Nepal and conserved ex situ

\begin{tabular}{lllllll}
\hline $\mathrm{SN}$ & District & Accession, $\mathrm{n}$ & $\%$ & $\mathrm{SN}$ & District & Accession, $\mathrm{n}$ \\
\hline
\end{tabular}




\begin{tabular}{|c|c|c|c|c|c|c|}
\hline \multicolumn{4}{|c|}{ A. Tarai and Inner Tarai districts } & \multicolumn{3}{|c|}{ B. Districts fall in both ecoregions } \\
\hline 1 & Banke & 58 & 1.96 & 22 Arghakhanchi & 28 & 0.94 \\
\hline 2 & Bara & 84 & 2.83 & Dandeldhura & 33 & 1.11 \\
\hline 3 & Bardiya & 12 & 0.4 & Dhankuta & 72 & 2.43 \\
\hline 4 & Chitwan & 16 & 0.54 & Doti & 39 & 1.32 \\
\hline 5 & Dang & 36 & 1.21 & Ilam & 56 & 1.89 \\
\hline 6 & Dhanusha & 74 & 2.5 & Makwanpur & 22 & 0.74 \\
\hline 7 & Jhapa & 100 & 3.37 & Palpa & 18 & 0.61 \\
\hline 8 & Kailali & 23 & 0.78 & Pyuthan & 13 & 0.44 \\
\hline 9 & Kanchanpur & 44 & 1.48 & Sallyan & 21 & 0.71 \\
\hline 10 & Kapilvastu & 40 & 1.35 & Sindhuli & 20 & 0.67 \\
\hline$\overline{11}$ & Mahottary & 74 & 2.5 & Surkhet & 31 & 1.05 \\
\hline 12 & Nawalparasi & 28 & 0.94 & Tanahun & 74 & 2.5 \\
\hline 13 & Parsa & 85 & 2.87 & Sub total & 427 & 14.41 \\
\hline 14 & Rautahat & 74 & 2.5 & C. Mid and high hill districts & 1158 & 39.04 \\
\hline 15 & Rupandehi & 38 & 1.28 & Unknown & 197 & 6.65 \\
\hline 16 & Saptari & 62 & 2.09 & Total & 2963 & 100 \\
\hline 17 & Sarlahi & 36 & 1.21 & & & \\
\hline 18 & Siraha & 82 & 2.77 & & & \\
\hline 19 & Sunsari & 115 & 3.88 & & & \\
\hline 20 & Udaypur & 50 & 1.69 & & & \\
\hline \multirow[t]{2}{*}{21} & Morang & 50 & 1.69 & & & \\
\hline & Sub total & 1181 & 39.84 & & & \\
\hline
\end{tabular}

Source: Gupta et al 2000.

Nepal has many locally adapted rice genotypes but only one has been used or improved for developing Nepalese Tarai and Inner Tarai rice cultivar. Trends of using local landraces are now increasing which help to check genetic erosion (B Chaudhary, Personal communication). Due to agro ecological differences Nepalese genotypes may contain unique genes (Table 2). These genes if conserved properly could be enough to fulfill rice grain demand in Nepal for next century. Diverse ethnic groups have great knowledge about the genotypes possessing unique characters. The possibility of starting a three lines heterosis breeding using local landraces was reported (Joshi et al 2003b). Among the 14 rice genotypes tested for their ability to restore fertility and maintain sterility, two landraces (Kature and Ratodhan) are restorers and other two (Deharadune and Chiunde) are maintainers (Joshi 2000a). Great potential of exploiting heterosis is possible using landraces and improved cultivars (Joshi 2000b, Joshi and Subedi 2001, Joshi 2003b). A set of 183 landraces were characterized and evaluated over space and time (1998-2000) (Sharma et al 2001). There was wide variation in maturity. Landraces were comparable with the improved cultivars. There is a possibility of breeding for new levels of grain yield and other economical characters using these landraces. Blast resistance was widely available in these landraces. More important genotypes should be identified and developed a strategy to use them. These genotypes may have potential role in developing suitable varieties and/or increasing national production. Clear advantages were indicated in using locally adapted parents and selection in the target environment compared to introduction from international nurseries, which usually perform poorly (Sthapit 1992). Characterization, evaluation and utilization of these landraces in breeding program by LARS, NRRP and ABD could certainly enhance the rice gene pool conservation. Landraces were mostly collected from western and eastern Nepal (Figure 2). The distribution pattern of rice could help to locate diverse rice areas and to implement in situ and on farm conservation and exploration program. This pattern suggests that there are diverse rice landraces adapted to different environments. Characterization and improvement of these landraces are necessary for long-term conservation and utilization. Due to the expansion of modern varieties these landraces are under threats of extinction. In addition, some of the landraces are under threat or extinct (Table 3) due to natural and human factors. Chang (1984) estimated more than 100,000 rice cultivars existed in Asia earlier in the $20^{\text {th }}$ century. But with the 
advent of modern, high yielding varieties and intensive cultivation, a small number of productive and relatively uniform cultivars now dominate commercial production (Chang 1994).

Table 2. Some of the unique rice genetic resources cultivated in Tarai, Inner Tarai, mid and high hills of

\begin{tabular}{lll}
\multicolumn{2}{c}{ Nepal } & \\
\hline SN & Genotype & Uniqueness \\
\hline 1 & Amaghauj & Multiple spikelets per node \\
2 & Anati or Anadi & Festival rice/ sticky rice/ medicinal value \\
3 & Bhati, Silhat & Deep water rice \\
4 & Chainon 2, Taichung 176 & Japonica type \\
5 & Chhommrong dhan, Jumli marshi & Cold tolerance rice, andilo \\
6 & Ekle rice & Zn deficiency tolerance \\
7 & Gamadi, Sathi & Panicle matured within flag leaf, early rice \\
8 & Ghayia & Upland rice \\
9 & Gurdi & Lodging susceptible \\
10 & IR 8, Jaya & Indica type \\
\hline 11 & Jarneli, Kathe Gurdi & Drought tolerance, secure grain yielder \\
12 & Jhinuwa & Good eating quality \\
13 & Kalanimak & Photo period sensitive \\
14 & Khera & God preferred landrace \\
15 & Laila Majnu or Jhodi dhan & Two grains in a lemma and palea \\
16 & Lalka basmati & Improtant for party \\
17 & Mansara, Mutmur, Anga & Adopted to very marginalized land \\
18 & Nal tumme & Shade loving rice \\
19 & Nakhisaro, Sathi, Laltenger & Pest resistance \\
20 & Pahele & Vitamin A content landrace (?) \\
\hline 21 & Pakhe Masino, Radha-4, Taichung, Lahure Sahila, & Hiunde (winter) rice \\
& Gori Sahila, Makar Kandhu & \\
22 & Parwanipur 1 & Ratoon rice \\
23 & Patle dhan & Good for pregnant women \\
24 & Samundaphinj & Swampy land rice \\
25 & Sokan dhan, Bageri & Resistance to BB and GLH $\ddagger$ \\
26 & Wild rice & Festival rice/ perenniality gene \\
\hline Hiunde rice (seeding at December and harvesting at May) has been cultivated since 35 years ago at Taruwa \\
VDC, Nawalparasi. This rice was extensively cultivated after 2042 BS (1984) in these areas. Farmer of this area, \\
Khadka Narayan Mahato has more knowledge on Hiunde rice. BB, Bacterial blight. GLH, Green leaf hopper. \\
Sources: Mallick (1981/82), NRRP (1997), Rijal (1998), Upadhyay and Joshi (2003). \\
& &
\end{tabular}




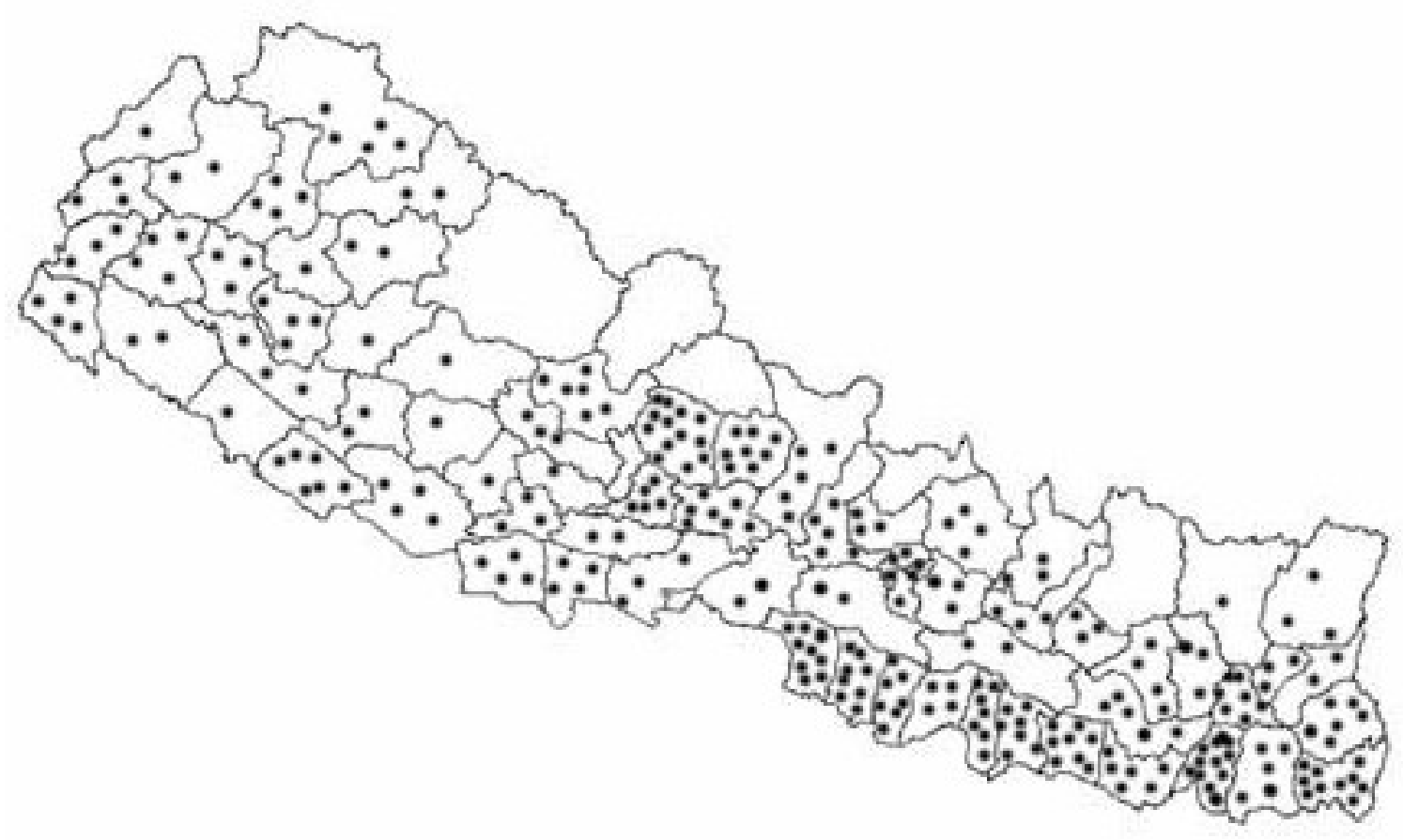

Figure 2. Distribution of rice diversity (more the number of dots more the diversity).

Table 3. Endangered and lost rice landraces in Tarai, Inner Tarai, mid and high hills of Nepal $\dagger$

\begin{tabular}{ll}
\hline Endangered (48) & Lost (105) \\
\hline Tauli, Thapachinia, Marsi, & Lahure Sahila, Gori Sahila, Makar Kandhu, Timaha, Darmali, Germani, \\
Mansara, Siraunla, Masind, & Koili, Budho thakale, Ghote, Salidhan, Jhauri, Bhamger, Lalka Pharam, \\
Nathani, Khalte Kolo, Biramphool, & Lajhi, Lohasaran, Parewa Pankha, Handiphul, Karma, Golabachhi, \\
Samundaphinj, Jhinuwa, Bayarni, & Dudhi Kariya, Bachhi, Devsar, Dudhraj, Sikhichanda, Galphuli Dutha, \\
Ramani, Pahenle Ghaiya, Bichare, & Rjana, Madhukari, Habsa, Ratin, Bansbarcli, Kanakjira, Ramjamai, \\
Basmati, Dudhe Marange, Pakhe & Ratan, Tulasiprasad, Mahajogi, Ramini Katika, Sankharika, Sokan, \\
Masino, Sindhuli, Pakhe Sali, & Baramphusi, Ghiukumari, Anandi, Manshara, Satraj, Barkhabahadur, \\
Jabaka, Charinangre, Pakhe & Pokhraj, Sankharika, Gondan, Maturi, Bhulani, Kuriya, Surkamiti, \\
Jhinuwa, Basaune Jhinuwa, & Satraj, Najhi, Golarato, Rajala, Megadoot, Dudhraj, Maturi, \\
Pahenle, jhinuwa, Gudura, Bardari, & Parweapankhe, Kariyakamod, Gaddar, Kanajira, Babadudhi, Bhulani, \\
Battisara, Pokhreli Jhinuwa, Pagate & Barkha Bahadur, Nakhi, Karma, Rati, Horinlduri, Gokulchanda, \\
Jhinuwa, Phente silange, Lalka & Maturi, Jhali, Gangaur, Dhudi, Katausi, Tulsi Prasad, Kanakjira, \\
Basmati, Soka, Sarho, Satraj, Lajhi, & Gokulchan, Sukhichand, Pakhar, Bansnareli, Karma, Silan, Akhidudhi, \\
Rango, Gajargul, Ratrani, Katuash, & Jhabri, Jajagaur, Satawa, Bangaluwa, Dudhisaro, Borch Bahadur, \\
Latongad, Masura, Dudhisaro, & Mutari, Amaghaur, Barbasaru, Jhali, Mashura, Gokhul, Handa, Kudiya, \\
Lalka Kartik, Ghuthani, Anadi, & Ramjamai, Kasturi, Dudha Kariya, Satariya, Changol, Golabati, \\
Khera, Mansari and Anga & Madhusar, Manshari \\
\hline
\end{tabular}

$\dagger$ not exhaustive. This information is mostly from western development region.

Sources: Upadhyay 1995, Rijal et al 1998, Joshi et al 1998, Sherchan et al 1998, Rana et al 2000c.

\section{Improved rice gene pool}

Twenty-eight improved rice varieties suitable to Tarai, Inner Tarai and Foot Hills of Nepal (Table 4a, 4b) are real efforts of researchers to be released during the period from 1959 to 2002. More numbers of crosses involving many parental lines in cultivars like Sabitri, Laxmi and Chaite 4 indicate the effort of scientists to collect value genes in single genotype. Use of different landraces in crossing program is a 
good strategy to increase yield (Joshi 2004). Six cultivars were released in 1987. The earliest released cultivar is China 45 in 1959. Shuttling of generation lines during winter season is also possible in Nepal, which helps to develop more rice cultivars within short period of time.

Table 4a. Improved rice varieties recommended for Tarai, Inner Tarai and foot hills of Nepal in Barkhe season

\begin{tabular}{|c|c|c|c|c|c|}
\hline $\mathrm{SN}$ & Variety & $\mathrm{Abb}$ & Pedigree & Parentage & Year released \\
\hline 1 & Barkhe-2 & $\mathrm{BKH} 2$ & B441b-126-3/2/2001 & C4-63GB/B531b -TK39 & 1987 \\
\hline 2 & Durga & DGA & IET 2938 & Jaya//IR8/Latisail & 1979 \\
\hline 3 & Ghaiya-2 & GHA2 & MW 10 & MTU15/Waikakku & 1987 \\
\hline 4 & IR20 & IR20 & IR 532E-576 & IR 262-24-3/TKM6 & 1972 \\
\hline 5 & IR22 & IR22 & IR 579-160-2 & IR 8/Tadukan & 1972 \\
\hline 6 & IR8 & IR8 & IR 8-288-3 & Peta/DGWG & 1968 \\
\hline 7 & Janaki & JNK & BG 90-2 & Peta*3/TN1//Remadja & 1979 \\
\hline 8 & Jaya & JAYA & - & $\mathrm{TN} 1 / \mathrm{T} 141$ & 1973 \\
\hline 9 & Khajura-2 & KAJ2 & PAU41-262 & RP72/Mutant65 & 1987 \\
\hline 10 & Makwanpur-1 & MKN & BG 400-1 & Ob678/IR20//H4 & 1987 \\
\hline 11 & Masuli & MAS & Mahsuri & Mayang Ebos $80 * 2 /$ Taichung 65 & 1973 \\
\hline 12 & Radha Krishna-9 & RA9 & NR 15016-24-1-3 & IR 42/Masuli & 1991 \\
\hline 13 & Radha-11 & RA11 & TCA $80-4$ & Local selection & 1995 \\
\hline 14 & Radha-12 & RA12 & OR 142-99 & TNI/T141//Annapurna & 1995 \\
\hline 15 & Radha-4 & RA4 & IR 8423-156-2-2-1 & BG 34-8/IR 2071-625-1 & 1995 \\
\hline 16 & Radha-7 & RA7 & NR 15013-40-1-1 & Janaki/Masuli & 1991 \\
\hline 17 & Rampur Masuli & RAMSULI & - & Lal Nakanda/IR30 & 1999 \\
\hline 18 & Sabitri & SAB & IR 2071-124-6-4 & IR 1561-228-1/IR 1737//CR 94-13 & 1979 \\
\hline
\end{tabular}

Source: NRRPa 1997.

Table 4b. Improved rice varieties recommended for Chaite season or first rice crop in the double rice cropped areas of Nepal (Recommended to Tarai and Inner Tarai)

\begin{tabular}{lllllc}
\hline SN & Variety & Abb & Pedigree & Parentage & Year released \\
\hline 1 & Bindeswari & BND & IET 1444 & TN 1/Co29 & 1981 \\
2 & China-45 & CH45 & China 45 & Selection at CRRI & 1959 \\
3 & Chaite-2 & CHT2 & IR7151-1260-3-3 & BG34-8/IR2061-522-6-9 & 1987 \\
4 & Chaite-4 & CHT4 & IR9729-67-3 & BG34-8/IR28//IR2071-625-1-252 & 1987 \\
5 & Chaite-6 & CHT6 & NR 274-7-3-3-1 & NR6-5-46-50/IR28 & 1991 \\
6 & Chandina & CND & IR532-1-176 & Peta*3/TN1//TKM6 & 1978 \\
7 & IR24 & IR24 & IR661-1-140-3 & IR8/// Century Patna/SLO//Sigadis & 1975 \\
8 & Laxmi & LAXMI & IR2061-628-1-6-4-3 & IR833-6-2-1-1//IR1561-149-1/IR1737 & 1979 \\
9 & Malika & MALI & Mala/J15 (IR272) & CP/SLO*2//Sigadis & 1982 \\
10 & Parwanipur-1 & PWP1 & IR400-29-2-73 & Peta* 4/TN1 & 1973 \\
\hline
\end{tabular}

Source: NRRPa 1997.

A total of 35 ancestors originated in 11 different countries were used to develop 28 rice cultivars (Table 5). Eight countries are the origins for 28 cultivars (Figure 3). These genes were mainly from Asian countries (Figure 4). Maximum ancestors were from India followed by Taiwan and Indonesia. Involvement of ancestors from 11 countries indicates the introduction of genes adapted to different geographic locations. A single landrace of each of seven countries (Figure 4) have been used in developing rice cultivars probably because of having value genes with them. Evidence shows that breeders can develop best varieties by reshuffling the genes from these wide collections. In Nepal 4 cultivars had been originated. Use of ancestors of both indica and japonica groups of sativa and nivara species indicated the collection of wide gene pools. Relatively more ancestors originated in more different countries were used for Nepalese wheat cultivars and mid and high hill rice cultivars development (Joshi and Mudwari 2003, Joshi 2003a) than Tarai and Inner Tarai rice cultivars. Evidence 
suggests that some modern varieties have a narrow genetic background. Lin (1991) has shown a narrow genetic background of japonica varieties released in Taiwan between 1940 to 1987. Dilday (1990) documented similar pattern for US rice cultivars. Concerns were raised about the narrow genetic diversity present among IRRI varieties (Hargrove 1979, Hargrove et al 1980, Chang 1994). All semidwarf cultivars have the $s d l$ gene for short plant stature. Most semidwarf cultivars derived from IR8 and other early IRRI releases carry the cytoplasm of Cina. All indica type rice hybrids in China share the $s d l$ gene and the wild abortive (WA) source of cytolasmic male sterility (Chang 1994).

Table 5. Ancestors used for developing Nepalese rice cultivars for Chaite and Barkhe Season for Tarai, Inner

\begin{tabular}{|c|c|c|c|c|c|c|}
\hline SN & Ancestor & $\mathrm{Abb}$ & Origin & Abb & Group & Snecies \\
\hline 1 & ANNAPURNA & ANNA & $?$ & $?$ & $?$ & $?$ \\
\hline 2 & B531B-TK39 & B531B & ? & ? & ? & ? \\
\hline 3 & C4-63-GB & $\mathrm{C} 4$ & ? & ? & ? & ? \\
\hline 4 & CENTURY PATNA & $\mathrm{CP}$ & USA & USA & INDICA & SATIVA \\
\hline 5 & CHINA-45 & $\mathrm{CH} 45$ & CHINA & $\mathrm{CHN}$ & ? & SATIVA \\
\hline 6 & CINA & CINA & CHINA & $\mathrm{CHN}$ & $?$ & SATIVA \\
\hline 7 & $\mathrm{CO}-18$ & $\mathrm{CO} 18$ & INDIA & IND & INDICA & SATIVA \\
\hline 8 & CO-29 & $\mathrm{CO} 29$ & INDIA & IND & INDICA & SATIVA \\
\hline 9 & DEE-GEO-WOO-GEN & DGWG & TAIWAN & TWN & INDICA & SATIVA \\
\hline 10 & GEB-24 & GEB24 & INDIA & IND & INDICA & SATIVA \\
\hline 11 & GP-15 & GP15 & ? & ? & ? & ? \\
\hline 12 & $\mathrm{H} 4$ & $\mathrm{H} 4$ & CEYLON & CLN & INDICA & SATIVA \\
\hline 13 & H501 & H501 & CEYLON & CLN & INDICA & ? \\
\hline 14 & LALNAKANDA & LKD & INDIA & IND & INDICA & ? \\
\hline 15 & LATISAIL & LAS & PAKISTAN & PAK & INDICA & SATIVA \\
\hline 16 & MAS & MAS & INDONESIA & IDO & INDICA & ? \\
\hline 17 & MAYANG EBOS-80 & ME80 & MALAYSIA & MAL & INDICA & SATIVA \\
\hline 18 & MTU15 & MTU15 & INDIA & IND & INDICA & SATIVA \\
\hline 19 & MUTANT-65 & MTNT 65 & ? & ? & $?$ & ? \\
\hline 20 & SHANKARA & SKR & NEPAL & NPL & INDICA & SATIVA \\
\hline 21 & O. NIVARA & ON & $?$ & $?$ & $?$ & NIVARA \\
\hline 22 & OB678 & OB678 & SRILANKA & SRI & ? & ? \\
\hline 23 & PP & PP & ? & $?$ & ? & ? \\
\hline 24 & PTB 18 & РTB 18 & INDIA & IND & INDICA & ? \\
\hline 25 & PTB 21 & РТВ 21 & INDIA & IND & INDICA & ? \\
\hline 26 & REMADJA & REM & INDONESIA & IDO & INDICA & SATIVA \\
\hline 27 & RP72 & RP72 & INDIA & IND & INDICA & SATIVA \\
\hline 28 & SIGADIS & SGO & INDONESIA & IDO & INDICA & SATIVA \\
\hline 29 & SLO & SLO & INDIA & IND & INDICA & SATIVA \\
\hline 30 & T141 & T141 & INDIA & IND & INDICA & SATIVA \\
\hline 31 & TADUKAN & TDKN & PHILIPPINES & PHL & INDICA & SATIVA \\
\hline 32 & TAICHUNG NATIVE1 & TN1 & TAIWAN & TWN & INDICA & SATIVA \\
\hline 33 & TAICHUNG-65 & T65 & TAIWAN & TWN & JAPONICA & SATIVA \\
\hline 34 & TCA-80-4 & TCA80 & INDIA & IND & INDICA & SATIVA \\
\hline 35 & WAIKAKKU & WKU & ? & $?$ & ? & $?$ \\
\hline
\end{tabular}

? Not known

Use of 35 ancestors from 11 different countries for tropical and sub tropical rice cultivars represent the great diversity in built in 28 Nepalese rice cultivars. The origins of 8 ancestors are not known. Ancestors were with different groups eg indica (65.71\%) and japonica (2.86\%). Groups and species of $31.43 \%$ and $37.14 \%$ ancestors respectively are not known. There were $60.00 \%$ sativa and $2.86 \%$ nivara ancestors species (Figure 5). Such diversity in species, origin and groups of ancestors have certainly enriched Nepalese rice biodiversity. 


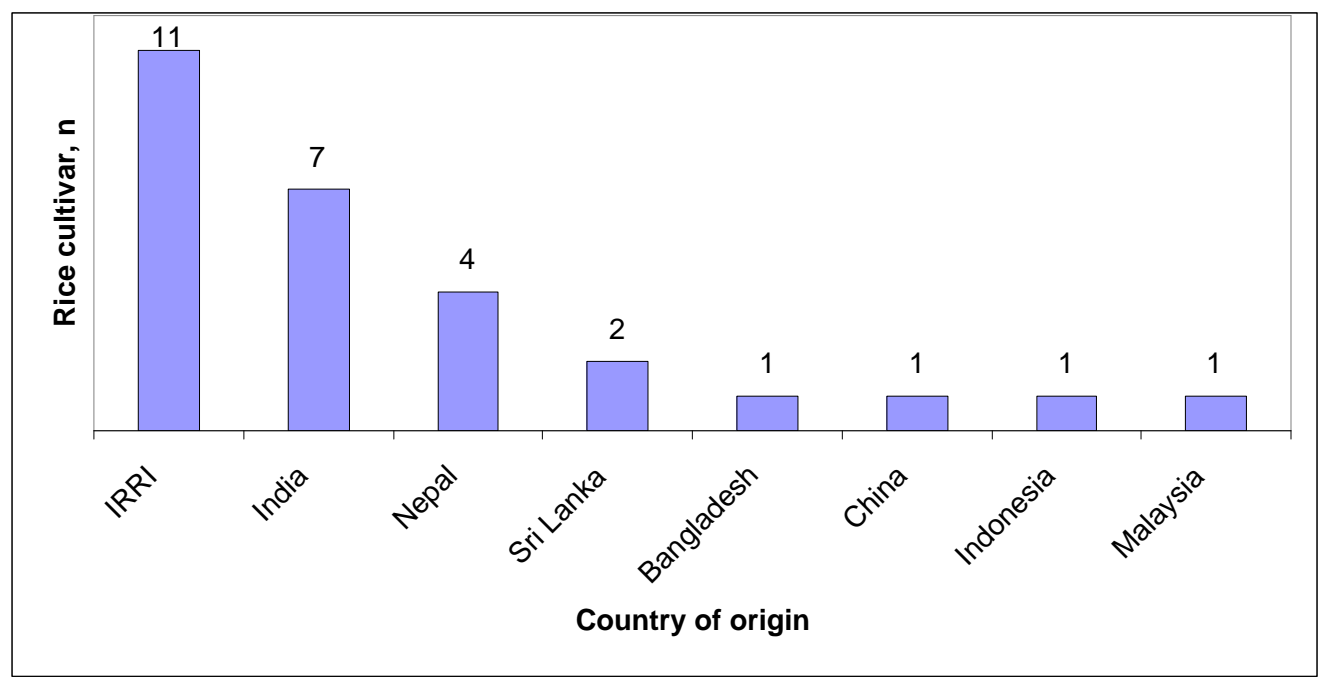

Figure 3. Countries of origin of 28 Tarai and Inner Tarai improved rice cultivars in Nepal.

Figure 4. Countries where the ancestors of Nepalese improved rice cultivars recommended for Tarai, Inner Tarai and foot hills were originated. Origins of 8 ancestors are not known.

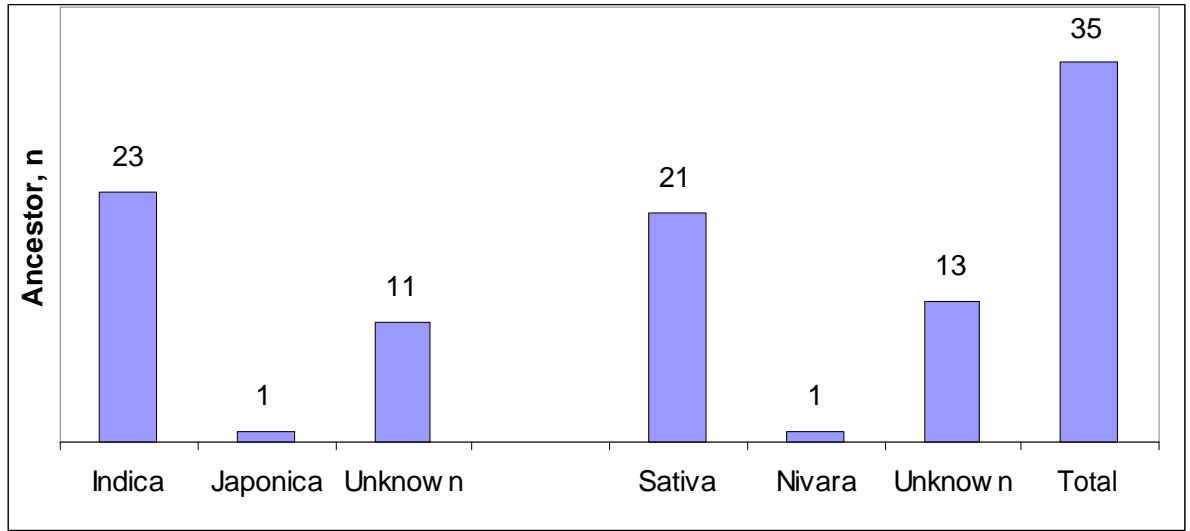

Figure 5. Ancestors' group used to develop Nepalese rice cultivars for Tarai and Inner Tarai.

\section{Wild rice gene pool}

Nepal being the center of diversity of rice, harbor the wild rice and its relatives in addition to diverse forms of landraces. Four wild rice species, Oryza nivara, O. rufipogan, O. granulata and O. officinalis are found in different areas of Nepal (Figure 6). Some of these areas are Ghodagodhi tal, Ajigara tal, Lothar, Jhapa, Illam, Sundarpur, Surkhet, Nijgada, Janakpur, Nepalgungj, Bara, Dang, Kapilbastu, Rupendehi, Birendranagar, Kaski, Palpa, Banke, Bardiya, Kancanpur etc (Table 6). Weedy rice, $O$. sativa f. spontanea is found in rice field across the country. Hygrooryza aristata and Leersia hexandra are other two species in related genera found in Nepal. These species are adapted to different ecological conditions in terms of altitude and water requirements, and distributed across the Tarai and mid hill. $O$. rufipogan, one of the natural parents of the present day cultivated rice is reported to have found in the northern most limit and the highest altitude in Nepal in the world (Shrestha and Upadhyay 1999). This extraordinary biological diversity in Nepal is due to geological, geographical and cultural factors. Very 
little attention has been given to wild rice diversity in Nepal. Nepal was considered as area of potentially new and useful genes for rice breeders (Shrestha and Upadhyay 1999). Wild species represent a rich pool of diversity particularly for their ability to withstand pests and diseases (Jackson 1995). Since wild germplasm is a valuable source for improving rice productivity and durability, explorations on those wild relatives are suggested followed by their proper characterization and utilization in the breeding program.

Table 6. Wild rice and wild relatives of rice found in different districts of Nepal

\begin{tabular}{|c|c|c|c|}
\hline SN & Wild /relative & Local name & Districts $\dagger$ \\
\hline 1 & Oryza nivara Sharma et Shastry & Tinna, Jhara & $\begin{array}{l}\text { Banke, Kapilbastu, Lumbini, Bardiya, } \\
\text { Kailali, Kanchanpur, Kaski, Dang, } \\
\text { Rupandehi }\end{array}$ \\
\hline 2 & $\begin{array}{l}\text { O. rufipogon Griff. } \\
\text { (O. perennis Moench.) }\end{array}$ & $\begin{array}{l}\text { Nabo ghans, Anga, } \\
\text { Salidhan }\end{array}$ & $\begin{array}{l}\text { Banke, Kapilbastu, Kailali, Kanchanpur, } \\
\text { Surkhet, Kaski, Palpa, Rupendehi, Dang }\end{array}$ \\
\hline 3 & $\begin{array}{l}\text { O. granulata Nees et Arn. ex } \\
\text { Watt. }\end{array}$ & $\begin{array}{l}\text { Ban dhan, Jangali } \\
\text { dhan, Sitarani dhan }\end{array}$ & Chitwan, Jhapa, Ilam, Makawanpur \\
\hline 4 & O. officinalis Wall ex Watt. & - & Kancahnpur, Bara, Janakpur \\
\hline 5 & $\begin{array}{l}\text { O. sativa f. spontanea (weedy } \\
\text { rice) }\end{array}$ & Navo, Thima, Jara & $\begin{array}{l}\text { Most of the rice growing districts, Rupandehi, } \\
\text { Kapilbastu, Banke, Bardiya, Kanchanpur, } \\
\text { Lamjung }\end{array}$ \\
\hline 6 & Hygroryza aristata & - & Kaski, Kailali, Kathmandu \\
\hline 7 & Leersia hexandra & - & Kaski, Lamjung, Kathmandu \\
\hline
\end{tabular}

$\uparrow$ Bold districts lie in Tarai and Inner Tarai of Nepal.

Sources: Shrestha and Updhyaya 1999, Sthapit 1999.

\section{Figure 6. Distribution of wild rice and related species in Nepal.}

Contributions of Nepalese PGR at national and international level have not been well documented. A total of 48 improved rice cultivars certainly have significant contributions at National economy. There are many more rice genotypes that have potential to make the Nepal difference. National and international organizations have explored and collected many rice genotypes from different parts of Nepal but their value and uses are very little known.

Despite high yielding attributes of improved cultivars compared to those of local types improved varieties were found to be susceptible to diseases and lodging (Shrestha 1976). There are many examples of improved varieties gaining popularity within a short period of time but later become susceptible to biotic stresses. Such trend was not reported in landraces. In this study, cultivars surveyed represent a wide range of variation for different areas of origin and adaptation. This genetic diversity may be useful for further rice improvement. The results of this study may help in the selection of the most diverse cultivars and greatly expand genetic variation for rice improvement. Cultivated landraces of indica and japonica type, wild rice and wild relatives of rice are found in Nepal. Gene pool from these landraces along with international gene pool could make to success in developing high yielding cultivars with wide adaptability. Developing cultivars possessing desired period of maturity, height and yield is seemed possible using this gene pool. However, modern varieties have been replacing the landraces and improved old varieties resulted in the genetic erosion. Therefore, in situ, on farm and ex situ conservations are necessary for maintaining the genetic variation. Government, semi governmental and private agencies should take action to conserve and utilize rice genetic diversity present in Nepal. 
There is need of identifying least cost in situ and ex situ conservation for rice landraces and wild rice gene pools and policy instruments most suitable for supporting conservation of this gene pool (D. Gauchan, personal communication). Participatory varietal selection (PVS) methodology has been selected to increase diversity in addition to increase the adoption rate of variety (Joshi et al 2003a). A prerequisite of conservation is genetic assessment of rice populations in the area that are likely to constitute rare, unique and distinctive genetic resources. Based on available information and genetic analysis, prediction of the future value of these genetic resources is needed in the extent to which they have high genetic value in improving yield potential and sustaining future rice productivity in the changing pest endemics, climate change and changes in market demand. We don't have favorable policy and legal for the protection of wild rice habitats. Molecular study is necessary to assess the diversity among ancestors (if possible) and cultivars derived from these ancestors. For effective conservation least cost methodologies for in situ, on farm and ex situ systems should be developed. Utilization of local landraces should be the first priority to conserve them in addition to increase the yield. Crossing program should be designed based on pedigrees information and local landraces. Potentiality of native genotypes should be made available. Varieties developed using local landraces will perform and adapt better than others. Duplicate accessions of ABD and LARS should be removed and gene bank must be updated through regular exploration program. To release cultivar, ancestors and number of crosses for that cultivar should be considered. For the conservation of wide gene pool, sitespecific trial rather than coordinated trial is recommended. Conservation work be initiated after genetic assessment of rice populations in the area that are likely to constitute rare, unique and distinctive resources. Specific technological options (plant breeding, biotechnology) for utilization of genes and appropriate economics instruments for providing incentives to community are suggested for conservation and utilization of rice diversity. For recommendation of any varieties microenvironment effects be considered. For Nepalese agro biodiversity conservation and utilization, plant breeding work should get first priority. Nepal has still many traditional farming systems. Based on the locality needs, these systems should be improved through participatory approach for overall plant genetic resources management.

\section{ACKNOWLEDGEMENTS}

Bedananda Chaudhary, Krishan P Shrestha, Hari B KC, Toefl Aktar and Bina Dongol for providing related information. Dedicated to my brother Bal Kumar and sister Dhana Kumari.

\section{REFERENCES}

Adhikari NP, MM Palikhe and RN Devkota. 1995. Status of rice, maize and wheat genetic resources in Nepal. In: Plant genetic resources: Nepalese perspective (MP Upadhyay, HK Saiju, BK Baniya and MS Bista, eds). Proceedings of National Workshop, 28 Nov-1 Dec 1994. NARI, IPGRI. Pp. 74-77.

Chang TT. 1984. Conservation of rice genetic resources: Luxury or necessary? Science 224:251-256.

Chang TT. 1994. The biodiversity crisis in Asia: Crop production and remedial measures. In: Biodiversity and terrestrial ecosystems (CL Peng and CH Chou, eds). Institute of Botany, Academia Sinica, Taipei. Monograph Series No. 14.

Cox TS, GL Lookhart, DE Walker, LG Harrell, LD Albers and DM Rogers (1985b). Genetic relationships among hard red winter wheat cultivars as evaluated by pedigree analysis and gliadin polyacrylamide gel electrophoretic patterns. Crop Sci., 25:1058-1062.

Cox TS, YT Kiang, MB Gorman, and DM Rogers. 1985a. Relationship between coefficient of parentage and genetic similarity indices in the soybean. Crop Sci. 25:529-532.

de Leon JC and AL Carpena. 1995. Pedigree based genetic diversity analysis of improved rice (Oryza sativa L.) varieties in the Philippines. Philipp. J. Crop Sci. 20:1-12. 
Dilday RH. 1990. Contribution of ancestral lines in the development of new cultivars of rice. Crop Sci. 30:905911.

Gupta SR, MP Upadhyay and DM Dongol (eds). 2000. Nepalese germplasm catalogue-2000. Agriculture Botany Division-NARC, Khumaltar-Lalitpur-Nepal.

Hargrove TR, WR Coffman and VL Cabanilla. 1980. Ancestry of improved cultivars of Asian rice. Crop Sci, 20:721-727.

Hargrove TR. 1979. Diffusion and adoption of semidwarf rice cultivars as parents in Asian rice breeding programs. Crop Sci. 19:571-574.

IRRI. 1970. Catalog of rice cultivars and breeding lines (Oryza sativa L.) in the world collection of the International Rice Research Institute. IRRI, Philippines.

IRRI. 1987. Final report of the twelfth international rice cold tolerance nursery. IRRI, Philippines.

IRRI. 2000a. The first international temperate rice observation nursery. INGER IRRI, Philippines.

IRRI. 2000b. The twenty seventh international rice blast nursery (IRBN 2000). INGER, IRRI, Philippines.

IRRI. GEU. Parentage of IRRI crosses IRI-IR30000. International Rice Research Institute, Philippines.

Jackson MT. 1995. Protecting the heritage of rice biodiversity. Geo Journal 35:267-274.

Joshi BK and A Mudwari. 2003. Wheat gene pool and its conservation in Nepal. Paper presented in the International Conference on Himalayan Biodiversity, 26-28 Jan 2003 Kathmandu, HIRI, Nepal.

Joshi BK and LP Subedi. 2001. Heterosis for growth and development characteristics in rice. Nepal J. Sci. Tech. 3:89-96.

Joshi BK, A Mudwari, MR Bhatta and GO Ferrera. 2004. Genetic diversity in Nepalese wheat cultivars based on agromorphological traits and coefficients of parentage. Nepal Agric Res J. 5:7-18.

Joshi BK, KP Shrestha, KD Joshi, A Mudwari, SP Khatiwada, P Chaudhary, RB Yadab, D Pandey, PR Tiwari, BK Baniya and BR Sthapit. 2003a. Process documentation on deployment rice and buckwheat diversity through participatory varietal selection for specific adaptation. In: On farm management of agricultural biodiversity in Nepal (BR Sthapit, MP Upadhyay, BK Baniya, A Subedi and BK Joshi, eds). Proceedings of National workshop, 24-26 April 2001, Lumle Nepal, Organized by NARC/LIBIRD/IPGRI. Pp.229-232.

Joshi BK, LP Subedi, SB Gurung and RC Sharma. 2003b. Evaluation of cultivars and landraces of Oryza sativa for restoring and maintaining wild aborted cytoplasm. Him. J. Sci. 1:87-91.

Joshi BK. 2000a. Assessment of the potential of Nepalese rice cultivars and landraces for hybrid production. Master thesis. IAAS, Rampur-Nepal.

Joshi BK. 2000b. Heterosis for yield and yield components in rice. Nepal Agri. Res. J. 4:6-13.

Joshi BK. 2003a. Rice gene pool for mid and high hills and its conservation in Nepal. Paper presented in Second SAS convention, 30 July - 1 Aug 2003. Khumaltar organized by NARC and SAS, Nepal.

Joshi BK. 2003b. Hybrid vigor in crosses of IR58025A with Nepalese rice cultivars. SARC Journal of Agriculture $1: 167-172$.

Joshi BK. 2004. Crossing frequency and ancestors used in developing Nepalese mid and high hill rice cultivars: Possible criteria for yield improvement and rice genes conservation. Paper presented in $4^{\text {th }}$ National conference on science and technology organized by RONAST, 23-26 March 2004, Kathmandu, Nepal.

Joshi KD, M Subedi, KB Kadayat and BR Sthapit. 1998. Factors and processes behind the erosion of crop genetic diversity in Nepal. In: Managing agrobiodiversity (T Partap and B Sthapit, eds). ICIMOD, IPGRI, Nepal. Pp.183-197.

Lin MS. 1991. Genetic base of japonica rice varieties released in Taiwan. Euphytica 56:43-46.

Mallick RN. 1981/82. Rice in Nepal. Kala Prakanshan, Kathmandu.

Martin JM, TK Balke and EA Hockett. 1991. Diversity among North American spring barley cultivars based on coefficients of parentage. Crop Sci. 31:1131-1137.

NRRP. 1992. Rice research reports. Proceedings of the $17^{\text {th }}$ National Summer Crops Workshop, 26-31 Jan 1992. National Rice Research Program, Hardinath, NARC, Nepal.

NRRP. 1997a. 25 Years of rice research in Nepal (1972-1997). National Rice Research Programme-NARC, Kathmandu.

NRRP. 1997b. Rice research reports. Proceedings of the $20^{\text {th }}$ national summer crops workshop, 22-24 April 1997. National Rice Research Program, Hardinath, NARC, Nepal.

Rana RB, CL Paudel, PR Tiwari, D Gauchan, A Subedi, BR Sthapit, MP Upadhyay and DI Jarvis. 2000a. In situ crop conservation: Findings of agro-ecological, crop-diversity and socio-economic baseline survey of Talium ecosite, Jumla, Nepal. NP Working Paper No 3/2000. NARC/LIBIRD /IPGRI, Nepal. 
Rana RB, DK Rijal, D Gauchan, BR Sthapit, A Subedi, MP Upadhyay, YR Pandey and DI Jarvis. 2000b. In situ crop conservation: Findings of agro-ecological, crop-diversity and socio-economic baseline survey of Begnas ecosite, Kaski, Nepal. NP Working Paper No 2/2000. NARC/LIBIRD /IPGRI, Nepal.

Rana RB, P Chaudhary, D Gauchan, SP Khatiwada, BR Sthapit, A Subedi, MP Upadhyay and DI Jarvis. 2000c. In situ crop conservation: Findings of agro-ecological, crop-diversity and socio-economic baseline survey of Kachorwa ecosite, Bara, Nepal. NP Working Paper No 1/2000. NARC/LIBIRD /IPGRI, Nepal.

Rijal DK, KB Kadayat, KD Joshi and BR Sthapit. 1998. Inventory of indigenous rainfed and aromatic rice landraces in Seti river valley, Pokhara, Nepal. LIBIRD Technical Paper No. 2.

Sharma RC, SM Shrestha, NK Chaudhary, MP Pandy, AK Tiwari, L Yadav, BR Ojha, BK Joshi, S Gyawali MP Upadhyay, S Sakrung and H Leurg. 2001. Characterization and improvement of Nepalese rice using molecular techniques. Terminal Report. The Rockefeller Foundation (Unpublished).

Sherchand KK, NP Adhikari, SP Khatiwada, AC Shrivastav, J Bajracharya, KD Joshi, KB Kadayat, M Chaudhary, P Chaudhary, SS Vishwakarma and S Yadav. 1998. Strengthening the scientific basis for in situ conservation of agrobiodiversity: Findings of site selection in Bara, Nepal. NP Working Paper No 2/98. NARC/LIBIRD/IPGRI, Nepal.

Shrestha GL and DA Vaughan. 1989. The wild relatives of rice in Nepal. Proc. of $6^{\text {th }}$ Internat'l Congress of SABRAO. Pp.171-174.

Shrestha GL and MP Upadhyay. 1999. Wild relatives of cultivated rice crops in Nepal. In: Wild relatives of cultivated plants in Nepal (R Shrestha and B Shrestha, eds). Proceedings of National Conference, June 2-4, 1999 Kathmandu, GEM, Nepal. Pp. 72-82.

Shrestha RB. 1976. Wheat production technology in Nepal. Nepalese Journal of Agriculture 6:18-24.

Souza E and ME Sorrells. 1989. Pedigree analysis of North American oat cultivars released from 1951 to 1985. Crop Sci. 29:595-601.

Sthapit BR. 1992. Chilling injuring of rice crop in Nepal: A review. J. Inst. Agric. Anim. Sci. 13:1-32.

Sthapit BR. 1999. In situ conservation of wild relatives of cultivated plants: Role of IPGRI in conservation and use in Nepal. In: Wild relatives of cultivated plants in Nepal (R Shrestha and B Shrestha, eds). Proceedings of National Conference, June 2-4, 1999 Kathmandu, GEM, Nepal. Pp. 56-71.

Upadhaya MP and BK Joshi. 2003. Plant genetic resources in SAARC countries: Their conservation and management- Nepal Chapter. Pp. 297-422.

Upadhyay MP. 1995. Food crop genetic resources. In: Plant genetic resources: Nepalese perspective (MP Upadhyay, HK Saiju, BK Baniya and MS Bista, eds). Proceedings of National Workshop, 28 Nov-1 Dec 1994. NARC, IPGRI, Nepal. Pp.35-41. 